\title{
Using Clove Essential Oil to Increase the Nutritional Potential of Industrial Fresh Double Cream Cheese
}

\author{
Ichrak Charfi ${ }^{1,2}{ }^{*}$, Cyrine Moussi², Hanene Ghazghazi ${ }^{3}$, Afwa Gorrab ${ }^{2}$, Riadh Louhichi ${ }^{4}$, \\ Salwa Bornaz ${ }^{1}$ \\ ${ }^{1}$ Ecole Supérieure des Industries Alimentaires de Tunis, Tunis, Tunisia \\ ${ }^{2}$ Université Libre de Tunis, Tunis, Tunisia \\ ${ }^{3}$ Laboratory of Management and Valorization of Forest Resources, National Institute for Research in Rural Engineering Water and \\ Forest (INRGREF), University of Carthage, Ariana, Tunisia \\ ${ }^{4}$ Le Groupement Interprofessionnel des Viandes Rouges et du Lait (GIVLait), Tunis, Tunisia \\ Email: *ichrak.charfi@gmail.com
}

How to cite this paper: Charfi, I., Moussi, C., Ghazghazi, H., Gorrab, A., Louhichi, R. and Bornaz, S. (2021) Using Clove Essential Oil to Increase the Nutritional Potential of Industrial Fresh Double Cream Cheese. Food and Nutrition Sciences, 12, 1269-1286. https://doi.org/10.4236/fns.2021.1212093

Received: May 20, 2021

Accepted: December 20, 2021

Published: December 23, 2021

Copyright (๐ 2021 by author(s) and Scientific Research Publishing Inc. This work is licensed under the Creative Commons Attribution International License (CC BY 4.0).

http://creativecommons.org/licenses/by/4.0/

\begin{abstract}
The present study was a potential application of Clove Essential Oil (CEO) in industrial fresh double cream cheese in order to lengthen its conservation and to improve its antioxidant potential. In this work, CEO was extracted by hydro distillation, and then analyzed by GC-MS; 24 components of clove essential oil were identified. Eugenol was the major component (57.66\%). Its antimicrobial properties against E. coli, Salmonella enteritidis and Staphylococcus aureus, were evaluated by disc diffusion method and minimal inhibitory concentration (MIC). As for, the antioxidant activity of CEO was evaluated by DPPH assay method. An optimum content of CEO (0.37\%) was calculated by mixing plan carried out by Expert design software and then added to studied cheese. The responses, fixed from the beginning, for this mixing plan were: minimum inhibitory concentration (MIC), antioxidant activity $\left(\mathrm{IC}_{50}\right)$, taste and odor intensity and global appreciation. The results found on the cheese supplemented with the optimum content of CEO showed antioxidant activity $\left(\mathrm{IC}_{50}=0.146\right)$ was relatively important compared to conventional cheese $\left(\mathrm{IC}_{50}=0.477\right)$. In fact, the incorporation of $\mathrm{CEO}$ in cheese may strongly improve its oxidative stability. Cheese antioxidant activity was not affected during the storage period for 13 days. Results showed also that the fresh double cream cheese could be stored at refrigerated temperature with good taste and odor during the period of 13 days due to antimicrobial properties given by CEO, that suggest lengthening its shelf life.
\end{abstract}




\section{Keywords}

Fresh Double Cream Cheese, Clove Essential Oil, Antimicrobial Activity, Antioxidant Stability

\section{Introduction}

Cheese is a fermented dairy product widely consumed in the world and which contains, in addition to its water content, other nutrients such as proteins, carbohydrates, vitamins and especially fat which gives it a very important nutritional value. However, this composition can make the cheese subject to different types of physicochemical and microbiological alterations [1]. From a hygienic and sensory point of view, an alteration in the nutritional quality of cheese can affect the health of the consumer. This alteration which is generally invisible is due to the proliferation and development of the pathogenic microorganisms responsible for food poisoning. These alterations can also modify the organoleptic characteristics such as alteration of taste, rancidity and odor defect, which make the product unmarketable. Recently, to fight against these types of deterioration and considering the increasing consumer demand for natural ingredients, several studies working in functional dairy products, investigated the incorporation of natural substances in cheese in order to enhance its preservation and its functionality. In fact, [2] [3] [4] studied the incorporation of the lysozyme, an antimicrobial agent in milk for cheese production thanks to its antimicrobial activity against a high number of pathogens. In other studies [5] [6] [7], different plant and fruit extracts with positive properties, commonly added to different types of cheese, in order to increase their functionality and their antioxidant capacity.

Most natural plant-derived antimicrobials can be highly effective in controlling foodborne pathogenic bacteria and extending shelf-life [8]. In addition, as in most cases, plants or their extracts are believed to be relatively safe for humans [9] [10]. In particular, many essential oils from various plants including edible and medicinal plants, herbs, and spices have been reported to be safe and possess strong antimicrobial effects [11] [12].

Several plant essential oils were also investigated due to their biological properties such as antimicrobial, antifungal and antioxidant activities [13] [14] [15]. These oils are classified as generally recognized as safe food additives in the United States [16]. Their use in foods has primarily been limited to flavor additives in soft drinks and sweets, and more recently as preservatives. In fact, actually, essential oil incorporation in foods, naturally in cheese, is among the hot topics in food functionalization branch, serving to lengthen their shelf life and increase their functionality [17] [18] [19] [20]. The World Health Organization (WHO) Expert Committee on Food Additives has established the acceptable daily human intake of $\mathrm{CEO}$ at $2.5 \mathrm{mg} / \mathrm{Kg}$ body weight for humans [21].

The aim of this study was a potential application of Clove Essential Oil (CEO) 
in industrial fresh double cream cheese in order to increase its preservation. Indeed, clove oil has shown several biological potentials [22] [23] [24]. Only a few studies have used CEO as a natural food preservative in soft cheese [25] [26], showing that $\mathrm{CEO}$ exhibited antimicrobial effectiveness against several food borne pathogens and high antioxidant activity in cheese.

\section{Materials and Methods}

\subsection{Clove Essential Oil (CEO) Extraction and Analysis}

Cloves were purchased from a supermarket (Ariana, Tunisia). They were crushed and then dried at $105^{\circ} \mathrm{C}$ for $4 \mathrm{~h}$. The dried material was subjected to hydrodistillation, using a Clevenger-type apparatus for $4 \mathrm{~h}$. The EOs were measured directly in the extraction burette and the amount of oil obtained (\%) was calculated as volume $(\mathrm{ml})$ of EO per $100 \mathrm{~g}$ of dry clove material. The oils obtained were dried over anhydrous sodium sulphate and stored in amber vials at $4^{\circ} \mathrm{C}$ before analysis [27].

\subsection{The Identification of CEO Constituents}

The constituents in CEO were identified through gas chromatography coupled to mass spectrometry-GC-MS under the following conditions: HP-5MS capillary column $(30 \mathrm{~m} \times 0.25 \mathrm{~mm}, 0.25 \mu \mathrm{m})$. The highest temperature of the column in oven for the elution was set to maximum $350^{\circ} \mathrm{C}$. The system was connected to a Perkin Elmer Clarus $60^{\circ} \mathrm{C}$ MS detector for identification of chemicals. The flow rate $(1.0 \mathrm{~mL} / \mathrm{min})$ of carrier gas helium $(\mathrm{He})$ of ultra-high purity was maintained constant during the whole separation process. The temperatures were set at $290^{\circ} \mathrm{C}, 280^{\circ} \mathrm{C}$ and $270^{\circ} \mathrm{C}$ for injection, transfer line and ion source, respectively. The $70 \mathrm{eV}$ chemical ionization energy was used for MS. The mass spectral data were collected in the scan range of $40-550 \mathrm{amu}$ by running the full-scan mass. The volatile oil was diluted and the $1 \mathrm{~mL}$ of sample was injected at a split ratio of 150:1. The temperature of the oven was programmed at $60^{\circ} \mathrm{C}$ and was increased gradually to $280^{\circ} \mathrm{C}$ with a constant rate of $3^{\circ} \mathrm{C} / \mathrm{min}$. The chemical class and nature of the compounds were established by matching the mass spectral data of CEO with the reference mass spectra.

\subsection{Total Polyphenols Determination}

Powdered CEO ( $5 \mathrm{~g}$ ) was extracted by maceration in ethanol at room temperature for one hour. The extract was filtered through Whatman no. 4 paper. The ethanolic extracts were evaporated at $35^{\circ} \mathrm{C}$ to dryness then stored in the dark at $4^{\circ} \mathrm{C}$ until use. Before testing, the dryness extract was freshly re-dissolved in ethanol at a final concentration of $100 \mathrm{mg} / \mathrm{mL}$ of ethanolic extract. Total polyphenols were carried out by the Folin-Ciocalteu method described by [28]. The Folin-Ciocalteu reagent has a yellow color, in an alkaline medium. It is reduced by phenols to a mixture of blue oxides of tungsten and molybdenum. Oxidation causes a color change from yellow to blue which absorbs at a wavelength $\lambda=750$ 
$\mathrm{nm}$. This coloration is proportional to the levels of phenolic compounds present in the sample. A calibration curve was prepared using gallic acid as a standard. The content of phenolic compounds was expressed in mg of gallic acid equivalent per g of CEO (mg GAE/g CEO).

\subsection{Antimicrobial Activities}

\subsubsection{Microorganisms and Growth Conditions}

The E. coli ATCC 25922, Salmonella enteritidis AT4 and S. aureus ATCC 25923, strains used in this study were obtained from Department of Biological engineer, Free University of Tunis (ULT), Tunis, Tunisia. The stock cultures were maintained in cryvials at $-80^{\circ} \mathrm{C}$.

Inocula of pathogenic bacteria strains used in antimicrobial testing were obtained after preparing suspensions in sterile saline solutions $(0.85 \% \mathrm{NaCl} \mathrm{p} / \mathrm{v})$, from overnight cultures grown in $\mathrm{BHI}$ agar at $37^{\circ} \mathrm{C}$. Each strain was grown in BHI broth at $37^{\circ} \mathrm{C}$ for $18-20 \mathrm{~h}$, harvested through centrifugation (4500 g, 15 $\min , 4^{\circ} \mathrm{C}$ ), washed twice in sterile saline solution and re-suspended in $\mathrm{BHI}$ broth to obtain standard cell solutions at which the OD reading at $660 \mathrm{~nm}$ was 0.1 which provided viable cell counts of approximately $8 \log \mathrm{CFU} / \mathrm{mL}$ for pathogenic strains when pourplated onto BHI agar [29].

\subsubsection{Disc Diffusion Method}

The disc diffusion method was conducted for the determination of antimicrobial activities of CEO against E. coli, Salmonella and $S$. aureus. Freshly cell suspension $(0.1 \mathrm{~mL})$ adjusted to $10^{8} \mathrm{CFU} / \mathrm{mL}$ for bacteria was spread in the plastic plates containing sterile Muller-Hinton-media (Bio Rad, France). Before use, CEO was diluted in DMSO to $10 \% \mathrm{v} / \mathrm{v}$, and sterilized by filtration through a 0.2 $\mu \mathrm{m}$ pore size filter. A Sterile filter paper discs $(6.0 \mathrm{~mm}$ in diameter) were soaked with $10 \mu \mathrm{L}$ already prepared CEO and placed on the surface of inoculated agar plates. All plates are left at room temperature for $30 \mathrm{~min}$ to allow diffusion of oil before inverting the plates for incubation. Salmonella plates, $S$. aureus plates and E. coli plates were incubated at $37^{\circ} \mathrm{C}$ for $24 \mathrm{~h}$. Control plates lacked exposure to CEO. The antibacterial activity was evaluated by measuring the diameter of the inhibition zone $(\mathrm{mm})$ around each disc. All tests were performed in triplicate [30].

\subsubsection{Minimal Inhibitory Concentration (MIC) Test}

The minimum inhibitory concentration (MIC) of CEO was determined using a macro-broth dilution technique. Inocula of pathogenic bacteria strains (E. coli, Salmonella enteritidis and $S$. aureus) were obtained after preparing suspensions from overnight cultures grown in $\mathrm{BHI}$ agar at $37^{\circ} \mathrm{C}$ as mentioned above providing viable cell counts of approximately $8 \log \mathrm{CFU} / \mathrm{mL}$.

Serial 2-Fold dilutions of the CEO were made in tubes in a total volume of 10 $\mathrm{mL}$ of DMSO that increase the solubility of the CEO. The concentration of clove oil in the test tubes ranged from $0.0008 \%$ to $1 \%$ (vol/vol). Broth cultures $(0.5 \mathrm{~mL}$ of $10^{8} \mathrm{CFU} / \mathrm{mL}$ ) of E. coli, Salmonella enteritidis and $S$. aureus already prepared, 
were then added to the tubes separately. Positive controls contain no CEO or DMSO. Negative controls were tubes containing DMSO but no EO.

The $E$. coli tubes, the Salmonella tubes and the $S$. aureus tubes were incubated at $37^{\circ} \mathrm{C}$ for $24 \mathrm{~h}$. Turbidity was visually determined for tubes containing pathogen strains, and least concentration of the oil at which no visible growth was recorded as the MIC of CEO on the selected strain. Results are reported as mean values from 3 replicate trials with each dilution used [24].

\subsection{Investigation of Antioxidant Activity by DPPH Assay Method}

CEO was investigated for its ability to scavenge free radicals by using $0.01 \mathrm{mM}$ DPPH in ethyl acetate as per the reported method of [21]. The experiment was performed in triplicate. The \% inhibition of $\mathrm{DPPH}$ radical was computed by the following formula:

$$
\text { The } \% \text { inhibition }=\frac{1-A_{S}}{A_{C}} \times 100
$$

where, $A_{C}=$ Absorbance of control without sample (containing DPPH solution except clove oil), and $A_{S}=$ Absorbance in the presence of clove essential oil. $\mathrm{DPPH}$. decreases significantly upon exposure to proton radical scavengers. $\mathrm{IC}_{50}$ which denotes the amount $(\mu \mathrm{g})$ of clove oil in $1.5 \mathrm{~mL}$ solution required to reduce initial concentration of DPPH radicals by $50 \%$ was also calculated.

\subsection{Determination of Optimal Concentration of CEO in Fresh Double Cream Cheese}

The incorporation of CEO in cheese aims to improve its oxidative and microbiological stability. As a result of this incorporation, the organoleptic properties of the cheese change, mainly the taste and smell. Therefore, we resorted to the use of a mixing plan using the Expert Design software (version 12), the aim of which is to set the optimal concentration of the CEO based on the results of antimicrobial and antioxidant activities and the sensory intensity (taste and smell) and global appreciation.

\subsection{Preparation of Inoculums}

E. coli, Salmonella enteritidis and $S$. aureus inoculums, that will be introduced into the cheese, part of this present study explained below, were prepared as described by [31]; cultures were activated in BHI broth. Cells were harvested by centrifugation $\left(10,000 \mathrm{~g} /\right.$ for $10 \mathrm{~min}$ at $\left.4^{\circ} \mathrm{C}\right)$, washed three times and re-suspended in Ringer's solution. The resulting pellet was washed once with Ringer's solution to remove residual organic material, re-centrifuged, and then re-suspended to a final volume of $10 \mathrm{~mL}$. The final inoculums were prepared with a final level of 5 $\log \mathrm{CFU} / \mathrm{ml}$. $0.1 \mathrm{~mL}$ of each pathogen was inoculated into pasteurized milk before manufacturing cheese in the second experiment.

\subsection{Manufacture of Cheese}

The fresh double cream cheese used in this work was manufactured according to 
the following procedure: raw cow's milk is acidified with lactic acid bacteria and rennet was added. When the curd $\mathrm{pH}$ reached a value of about 6 , the whey was removed and the curd was pressed. Then the cream and the salt were added and the whole was then kneaded. Samples about $16 \mathrm{~g}$ were packaged in polypropylene in square form. The samples were stored at $4^{\circ} \mathrm{C}$.

Two experiments were done after preliminary experiments carried out for the mixing plan in order to determine the optimal dose of CEO to incorporate into the cheese:

The first experiment served as control experiment. The first batch was fresh double cream cheese (-CEO) manufactured as described below and the second batch was the cheese supplemented with the optimum concentration of CEO $(+\mathrm{CEO})$. At intervals of $0,2,7$ and 13 days of storage at $4^{\circ} \mathrm{C}$, samples were analyzed for total coliforms (TC) count, fecal coliforms (FC) count and for antioxidant activity.

The second experiment was used to evaluate the antimicrobial activity of CEO in cheese. The first batch was artificially inoculated with mixture culture from $E$. coli, Salmonella enteritidis and S.aureus without CEO and served as the control.

The second batch was artificially inoculated with mixture culture from E. coli, Salmonella enteridis and $S$. aureus and supplemented with the optimum concentration of CEO. At intervals of $0,2,7$ and 13 days of storage at $4{ }^{\circ} \mathrm{C}$, samples were analyzed for E. coli, Salmonella enteritidis and $S$. aureus count during storage. The whole experiment was run in triplicate.

\subsection{Microbial Cheese Characterization}

Once the optimization is done by the mixing plan and the CEO concentration is set, the cheese samples; the cheese incorporated with $\mathrm{CEO}$ and the standard one $(-\mathrm{CEO})$ are analyzed:

Three samples were microbiologically examined for each type of cheese (standard and cheese with CEO) after 0, 2, 7 and 13 days of production. $25 \mathrm{~g}$ of cheese samples were added aseptically to $225 \mathrm{~mL}$ of sterile peptone saline diluents and homogenized in a stomacher. Total coliform was enumerated on MacConkey agar with a double layer of the same medium at $37^{\circ} \mathrm{C}$ for $24 \mathrm{~h}$. Fecal coliforms were counted on MacConkey agar at $44^{\circ} \mathrm{C}$ for $24 \mathrm{~h}$. E. coli strain was counted on Muller Hinton agar at $37^{\circ} \mathrm{C}$ for $24 \mathrm{~h}$. S. aureus was counted on Baired Parker agar at $37^{\circ} \mathrm{C}$ for $24 \mathrm{~h}$.

For Salmonella isolation, $25 \mathrm{~g}$ cheese samples were placed in $225 \mathrm{~mL}$ of peptone water and incubated at $36^{\circ} \mathrm{C} \pm 1{ }^{\circ} \mathrm{C}$ for 8 to $18 \mathrm{~h}$. A $1-\mathrm{mL}$ aliquot of pre-enriched culture was trans-ferred to a $10-\mathrm{mL}$ aliquot of tetrathionate (TT) broth and selenite cystine (SC) broth. The TT was incubated at $42^{\circ} \mathrm{C} \pm 1{ }^{\circ} \mathrm{C}$ and SC at $36^{\circ} \mathrm{C} \pm 1^{\circ} \mathrm{C}$ for 18 to $24 \mathrm{~h}$. One loop of TT broth was streaked onto bismuth sulfite and SC broth onto Hektoen enteric (HE; Beijing Land Bridge Technology Co. Ltd.) agars. The BS plates were incubated at $36^{\circ} \mathrm{C} \pm 1^{\circ} \mathrm{C}$ for 40 to $48 \mathrm{~h}$ and HE plates for 18 to $24 \mathrm{~h}$, and examined for the presence of Salmonella as described by [32] 


\subsection{Cheese Antioxidant Activity Determination}

The antioxidant activity of the new fresh double cream cheese with CEO was also determined as follows: One $\mathrm{mL}$ of $(0.1 \mathrm{Mm})$ ethanolic solution of DPPH was added to $3 \mathrm{~mL}$ of different water extracts $(10-250 \mu \mathrm{g} / \mathrm{mL})$. After $30 \mathrm{~min}$ of incubation at room temperature, the absorbance was measured against a blank at $517 \mathrm{~nm}$ and the inhibition of free radical DPPH in percent (\%) was calculated as described below [26].

\subsection{Sensory Evaluation}

Samples of fresh double cream cheese supplemented with different concentrations of CEO using in the mixing plan as preliminary experiment were sensorial evaluated in order to choose the optimal concentration of CEO to incorporate into the cheese.

The evaluation was carried out by fifteen panelists who were selected according to their interest in the sensory evaluation of dairy products. Cheese samples were equilibrated to room temperature immediately before testing and then evaluated for "odor" and "taste" intensity and global judgment using a 5 point scale: $0=$ not perceptible, $1=$ barely perceptible, $2=$ low intensity, $3=$ medium intensity, 4 = great intensity, and 5 extreme intensity.

\subsection{Statistical Analysis}

Data were statistically analyzed using ANOVA variance analysis through the general linear model (GLM) procedure of the statistical analysis software (SAS, version 9.1). Least significant differences were used to separate means at $p<$ 0.05 .

\section{Results and Discussion}

\subsection{Percentage Yield and Chemical Composition of Extracted CEO}

CEO was obtained in 5\% v/w yield and was lower than the amount (8.23\%) reported in a study previously done [33]. CEO yield variation as well as its chemical composition depend on various factors including environment, time of collection, cultivation practices and the methods used to extract it [33] [34]. 24 compounds representing $99 \%$ of the total detected constituents were identified with the help of GC-MS analysis. Eugenol (57.66\%) and caryophyllene (14.57\%), acetyl eugenol (5.96\%), $\alpha$-caryophyllene $(4.57 \%)$ were identified as CEO major constituents. These constituents were identified in previous studies with comparable amounts [35] [36].

Numerous studies have identified and quantified similar chemical compounds in the essential oils of Syzigium aromaticum, revealing that this species has a similar chemotype to eugenol-rich chemotype. Eugenol was identified as a major compound (90.3\%) in an essential oil extracted from the south of Brazil, in addition to $\beta$-caryophyllene (4.83\%) and eugenol acetate (1.87\%) [37], while another study, also on essential oil of cloves from the south of Brazil, observed the pres- 
ence of eugenol (56.06\%) and caryophyllene (39.63\%) in greater quantities [38], very similar to the amount found in the present study. Syzigium aromaticum essential oils obtained in China [39] and in Italy [40] also had eugenol as their major compound, with $90.84 \%$ and $77.9 \%$, respectively. [41] confirmed by GC-MS the presence of eugenol (53.23\%) as the major compound.

\subsection{Total Phenol Compounds Content}

The total phenolic compounds content in CEO was $12.05 \mathrm{mg} \mathrm{GAE} / \mathrm{g}$, which was lower than values reported by [42] (18.59 $\mathrm{mg} \mathrm{GAE} / \mathrm{g}$ ) and higher than values reported by [38] (9.07 GAE mg/g). Total phenolic compounds concentration is dependent on the oil extraction method and the characteristics of the sample. The phenolic components and more precisely methoxy phenols are known to be strong scavengers of free radicals; therefore, the antioxidant activity of CEO could be attributed to its major phenolic compound eugenol.

Previous studies also showed that clove had a high level of phenolics [43] [44]. The variation in the recovery of phenolics from natural products may be influenced by the type of plant material, the chemical nature of the extractable compounds and the effectiveness of extraction solvents to solubilize such compounds [45].

\subsection{Antimicrobial Activity}

In the present study, the CEO was able to inhibit growth of tested pathogenic bacteria. The results were discussed on the basis of the diameter of zone of inhibition in $\mathrm{mm}$. The CEO had varying degrees of growth inhibition against the tested microorganisms; the value of the zone inhibition ranged from 11 to 23 $\mathrm{mm}$ (Table 1). In previous works, the antibacterial activity of clove essential oil was tested against various strains of pathogens in particular strains tested in our work. Results have shown that $\mathrm{CEO}$ was with a wide spectrum of antibacterial activity [46] [47]. The CEO, used at the rate of $10 \mu \mathrm{L} /$ disc had the widest ZI with Staphylococcus aureus $(p<0.05 \%)$, a smaller ZI for E. coli and the most restricted ZI for Salmonella enteritidis. The results of the zones of inhibition against these pathogens displayed in Table 1 of CEO showed that $S$. aureus and E. coli presented higher sensitivity to CEO (ZI $>20 \mathrm{~mm}$ ), while Salmonella enteritidis was less sensitive $(\mathrm{ZI}=11 \mathrm{~mm})$. The inhibition zone of CEO against Salmonella obtained in the present study was similar to the findings of previous study

Table 1. Zone of inhibition of E. coli, Salmonella enteritidis and $S$. aureus By CEO determined by disc diffusion assay.

\begin{tabular}{cccc}
\hline & E. coli & Salmonella enteritidis & S. aureus \\
\hline Clove oil ZI $(\mathrm{mm})$ & $23 \pm 0.5^{\mathrm{a}}$ & $11 \pm 0.2^{\mathrm{b}}$ & $21 \pm 0.4^{\mathrm{c}}$ \\
\hline
\end{tabular}

${ }^{\mathrm{a}-\mathrm{c}}$ Within columns, means without common subscripts are significantly different $(p<$ $0.05 \%)$. Zone of inhibition is expressed as diameter in millimeters. Values represent means of inhibition zones of 2 independent experiments; $n=8$. Individual undiluted essential oils were used at the rate of $10 \mathrm{~mL} /$ disc. 
of the same essential oil [48]. However, the zones inhibitions of CEO against $E$. coli and $S$. aureus tested were distinct of those observed by [31].

\subsection{MIC Determination}

The macro-broth dilution method was used to confirm the findings of the disc diffusion assay and to determine the inhibitory concentrations. Essential oils are not soluble in water due to their hydrophobic compounds, and it was therefore necessary to add DMSO as emulsifier. The negative controls with DMSO showed no antibacterial activity. The MIC against the studied bacteria (Table 2) was about $0.23 \%-0.40 \%$. These concentrations of the CEO gave a maximum inhibitory effect on bacterial pathogens while an increase in concentration did not produce any significant changes and gave unacceptable sensorial attributions in cheese. The inhibitory concentrations reported in other clove essential oil studies varied from $0.04 \%$ to $2 \%$ [24] [48] [49]. The antimicrobial activity of CEO was mainly due to eugenol; its major compound. However, in some studies, researches have suggested that the whole CEO has a higher antibacterial effect than individual components, suggesting that the minor components in the oil are also crucial for the observed activity [24].

\subsection{CEO Antioxidant Activity}

The antioxidant activity of CEO against 1,1diphenyl picrylhydrazyl (DPPH) radical was determined by in vitro colorimetric assay. This method was adopted to study antioxidant activity because of the stability and unique purple color of free radicals of DPPH at room temperature. The intensity of purple color $\left(l_{\max }=\right.$ $517 \mathrm{~nm}$ ) diminished after being reduced by electron or hydrogen radical donated by antioxidant compound. Therefore the antioxidant power of volatile oil is determined by their ability to reduce DPPH radical which is measured by recording the lowering in absorbance values. The results were shown by $\mathrm{IC}_{50}$ value, which is the concentration of a compound that will induce half of the maximum action.

The DPPH scavenging activity of CEO at the concentration of $40 \mu \mathrm{g} / \mathrm{mL}$ was 85.4\%. A similar stronger DPPH scavenging activity was found for the CEO; [21] reported $83.6 \%$ of scavenging at the concentration level of $45 \mu \mathrm{g} / \mathrm{mL}$. The $\mathrm{IC}_{50}$ value of CEO used in this present work was calculated as $0.096 \mathrm{mg} / \mathrm{mL}$ indicating it to have good antioxidant potential but less important that the antioxidant potential found by $[20]\left(\mathrm{EC}_{50}=0.021 \mathrm{mg} / \mathrm{mL}\right)$.

Table 2. Minimum inhibitory concentration of CEO on E. coli, Salmonella enteritidis and S. aureus 1 .

\begin{tabular}{cccc}
\hline & E. coli & Salmonella enteritidis & S. aureus \\
\hline Clove oil (\%) & $0.023 \pm 0.05$ & $0.04 \pm 0.05$ & $0.023 \pm 0.02$ \\
\hline
\end{tabular}

${ }^{1}$ Inhibitory concentrations are average values of two independent trials. Each value is an average of 3 observations. The minimum inhibitory concentration was run in a total volume of $10 \mathrm{~mL}$. 
It was mentioned that the effect of geographic origin can influence the antioxidant activity of EOs. These variations were probably due to differences in phenolic compounds' content [27]. Due to their hydroxyl groups that allow them to inhibit DPPH free radicals, phenols were considered as the major factor contributing to antioxidant activity of plants. Indeed, [50] showed a positive correlation between total phenolic compounds content and antioxidant activity.

Thanks to its higher antioxidant activity, CEO could be proposed as a potential alternative to natural antioxidants.

\subsection{Optimal Concentration of CEO in Fresh Double Cream Cheese}

In order to determine the appropriate dose of CEO to incorporate into the fresh double cream cheese, we used "Expert Design" software which served us as a mixing plan with 4 answers, namely, taste, smell, global judgment and rating of antioxidant activity. These different responses were at the origin of a series of 8 experiments carried out on our cheese according to the mixing plan (Table 3 ).

The Expert Design optimization module will look for a combination that simultaneously meets the requirements for each response. In this case, the suitable dose is presented in Table 4.

The optimal dose of CEO determined by mixing plan was about $0.37 \%(\mathrm{v}, \mathrm{w})$ which corresponds to an antioxidant activity equal to 0.15 , expressed by $\mathrm{IC}_{50}$. More $\mathrm{IC}_{50}$ is reduced, more the antioxidant activity is important. In fact, we noticed that the $\mathrm{IC}_{50}$ value decreased significantly (more than three times) from $\mathrm{IC}_{50}=0.477$ (cheese $-\mathrm{CEO}$, trials 2 and 3 ) to $\mathrm{IC}_{50}=0.15$ (Cheese + optimal dose

Table 3. Mixing plan developed by expert design software.

\begin{tabular}{|c|c|c|c|c|c|c|}
\hline Run & $\begin{array}{c}\text { Component } \\
\text { A: CEO } \\
\%\end{array}$ & $\begin{array}{c}\text { Component } \\
\text { B: Cheese } \\
\%\end{array}$ & $\begin{array}{c}\text { Response } \\
1 \\
\text { Taste }\end{array}$ & $\begin{array}{c}\text { Response } \\
2 \\
\text { Smell }\end{array}$ & $\begin{array}{c}\text { Response } 3 \\
\text { Global } \\
\text { appreciation }\end{array}$ & $\begin{array}{c}\text { Response } 4 \\
\text { Antioxidant } \\
\text { activity }\left(\mathrm{IC}_{50}\right)\end{array}$ \\
\hline 1 & 0.38 & 99.63 & 1.92 & 3.33 & 1.91 & 0.21 \\
\hline 2 & 0.00 & 100.00 & 0.84 & 0.53 & 2.69 & 0.48 \\
\hline 3 & 0.00 & 100.00 & 0.84 & 0.53 & 2.59 & 0.48 \\
\hline 4 & 0.25 & 99.75 & 1.84 & 2.07 & 1.76 & 0.24 \\
\hline 5 & 0.13 & 99.88 & 1.60 & 1.76 & 2.23 & 0.44 \\
\hline 6 & 0.50 & 99.50 & 2.92 & 3.76 & 1.00 & 0.0007 \\
\hline 7 & 0.25 & 99.75 & 1.84 & 2.07 & 1.76 & 0.24 \\
\hline 8 & 0.50 & 99.50 & 2.92 & 3.76 & 1.00 & 0.0007 \\
\hline
\end{tabular}

Table 4. Optimization of the suitable CEO concentration by expert design software.

\begin{tabular}{ccccccc}
\hline $\begin{array}{c}\text { Solutions } \\
\text { Number }\end{array}$ & $\begin{array}{c}\text { A } \\
\%\end{array}$ & $\begin{array}{c}\text { B } \\
\%\end{array}$ & Taste & Smell & $\begin{array}{c}\text { Global } \\
\text { appreciation }\end{array}$ & $\begin{array}{c}\text { Antioxidant } \\
\text { activity }\end{array}$ \\
\hline 1 & 0.37 & 99.63 & 1.96 & 3.00 & 1.50 & 0.15 \\
\hline
\end{tabular}


of CEO). Thanks to the high antioxidant activity given, we can conclude that the incorporation of $\mathrm{CEO}$ in cheese may strongly improve its oxidative stability. This optimum CEO concentration was used for the new formulation which is controlled for 13 days of storage at $4^{\circ} \mathrm{C}$.

Flavor is the sensation produced by a material taken in the mouth, perceived mostly by the senses of taste and smell. Data shown in Table 4 indicated the new formulation with the optimum CEO concentration presented a weakly intense taste and moderately intense smell. Compared to the results of cheese used as control (run 2, Table 3), CEO showed a significant effect on the taste, smell and global appreciation.

This difference can be explained by the nature of its chemical composition; CEO consists of a mixture of aliphatic and cyclic volatile terpenes and phenylpropanoids, which are considered as very aromatic compounds [51].

\subsection{Pathogenic Bacteria in Fresh Double Cream Cheese Supplemented with CEO}

Cheese is a food rich in nutrients, which makes it a favorable environment for development of microorganisms. For this reason, the count of germs will be essential to know total and fecal coliforms, in cheese samples used for the first experiment (batch 1; Control cheese and batch 2; Cheese incorporated with optimum dose of CEO).

Total coliform were present in cheese samples from batch 1 and batch 2 (experiment 1) with a lower concentration in cheese from batch $2(+\mathrm{CEO})$. The presence of coliform in cheese can be due to a lack of hygiene in the environment of the cattle, either during treats or at the storage level. The presence of fecal coliform is also due to fecal contamination of animal origin [52]. The results show that in the presence of essential oil of clove, the number of total coliform decreased by about half and fecal coliform weakly present in cheese (-CEO) (experiment 1, bach 1) were completely eliminated in cheese supplemented with CEO (experiment 1, bach 2). These changes were preserved for 13 days of cold storage. The reduction in the bacterial count confirmed the antimicrobial action of bioactive compounds in CEO which mainly contain phenolic compounds causing bacteriostatic and antiproliferative actions against bacterial growth.

Total coliform count for cheese form batches 1 and 2 increased during cold storage. The magnitude of increase in total coliform count was more important in cheese from batch 1 , compared with cheese from batch 2 . The microbiological monitoring of the 2 batches of cheese (first experiment) during storage is presented in Figure 1.

In general, essential oils have an important potential to protect foods against the growth of pathogens. The antimicrobial activity of essential oils depends on their chemical composition, mainly the major volatile compounds. During storage, the reduction in the rate of germs in the cheese, in the presence of CEO, 


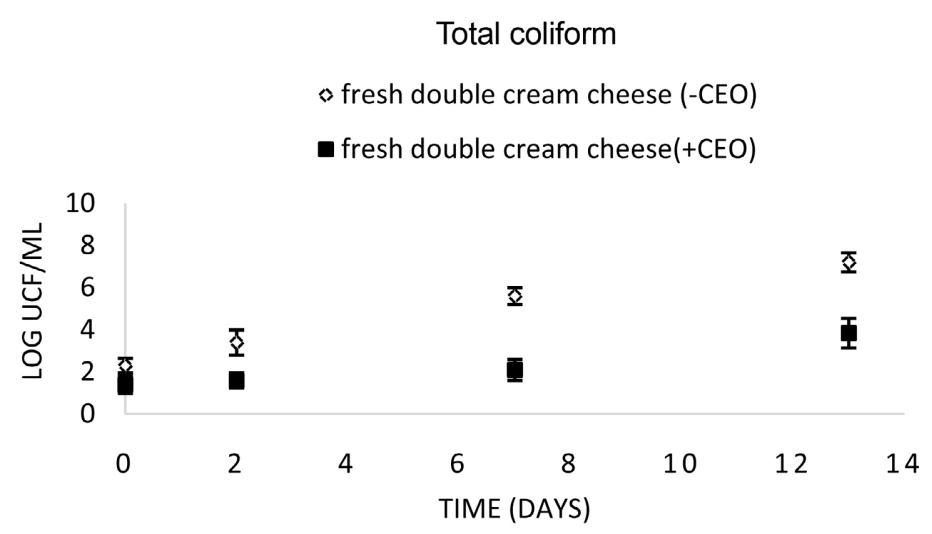

Figure 1. Total coliform count in fresh double cream cheese (control) and cheeses supplemented with $\mathrm{CEO}$ during cold storage $\left(4^{\circ} \mathrm{C}\right)$ for 13 days.

can reduce the risk of cheese spoilage, so the possibility of using this essential oil as a natural preservative.

The data in Figure 2 showed the changes in the level of E. coli, Salmonella enteritidis and $S$. aureus in cheese supplemented with CEO (batch 2, Experiment 2) compared to cheese without $\mathrm{CEO}$ (control) during 13 days of cold storage. The cheese was inoculated with a mixture culture of bacteria at $4.15 \mathrm{log}$ $\mathrm{CFU} / \mathrm{mL}$. In control cheese, the three microorganisms grew with cold storage time, with a higher rate of growth in case of $E$. coli which reached a maximum of $4.80 \log \mathrm{CFU} / \mathrm{mL}$ against $4.49 \log \mathrm{CFU} / \mathrm{mL}$ in case of $S$. aureus and $4.30 \log$ $\mathrm{CFU} / \mathrm{mL}$ in case of Salmonella enteritidis after 13 days of cold storage.

Supplementation with optimum concentration of CEO exerted a significant reducing effect against the proliferation of the three pathogens. E. coli, Salmonella enteritidis and $S$. aureus were reduced after 13 days of storage with magnitudes of reduction were respectively $1.25,1.35$ and $1.14 \log \mathrm{CFU} / \mathrm{ml}$. These results confirmed the results above concerning the important antimicrobial potential of CEO in these three pathogens. Based on the findings, it can be stated that CEO has general antibacterial activities against pathogens. This high antimicrobial power can contribute to keep a good hygienic quality of cheese during storage under cold conditions.

\subsection{Cheese Antioxidant Activity Evaluation}

The DPPH scavenging activity was expressed by the $\mathrm{IC}_{50}$ value of clove fresh cheese at $4^{\circ} \mathrm{C}$ during storage period for 13 days (Table 5). It was demonstrated that the incorporation of $0.37 \%$ of $\mathrm{CEO}$ in fresh double cream cheese, during its manufacturing increased significantly $(p \geq 0.005)$ its antioxidant activity, which stayed stable during cold storage period. These results were in agreement with the results obtained by [26] [53].

Fresh double cream cheese is a very alterable matrix due to its richness in water, sugar and fat. The addition of CEO in its formulation enriched it with natural antioxidants, presenting significant oxidation stability potential. In addition, 

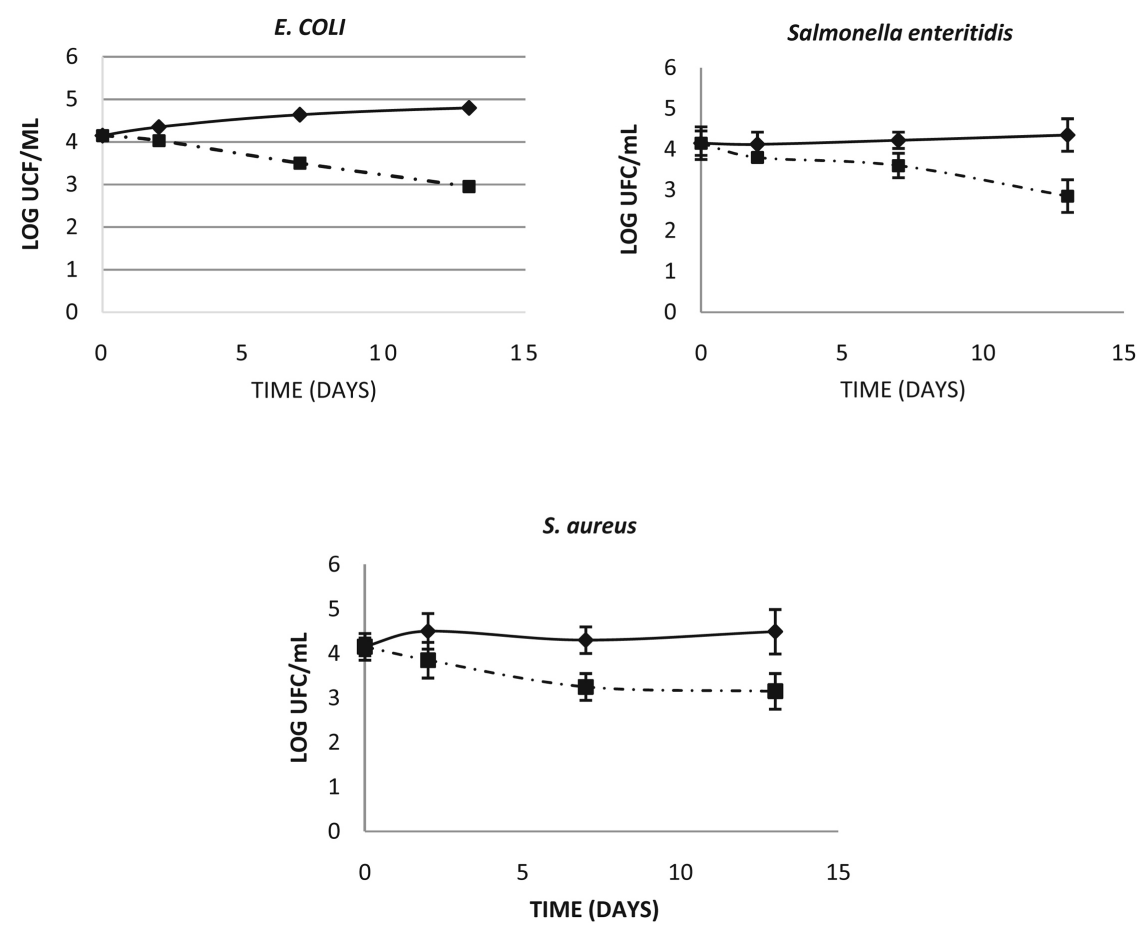

Figure 2. Changes in the counts of pathogens (E. coli, Salmonella enteritidis, S. aureus) inoculated into fresh double cream cheese (control) and cheeses supplemented with CEO during cold storage $\left(4^{\circ} \mathrm{C}\right)$ for 13 days.

Table 5. The antioxidant activity $\left(\mathrm{IC}_{50}\right)$ of fresh double cream cheese supplemented with CEO during storage for 13 days at cold storage.

\begin{tabular}{ccccc}
\hline $\begin{array}{c}\text { Storage period } \\
\left(4^{\circ} \mathrm{C} \pm 2^{\circ} \mathrm{C}\right)\end{array}$ & 0 day & 2 days & 7 days & 13 days \\
\hline Cheese $-\mathrm{CEO}$ & $0.477^{\mathrm{A}, \mathrm{a}} \pm 0.33$ & $0.490^{\mathrm{A}, \mathrm{a}} \pm 0.21$ & $0.481^{\mathrm{A}, \mathrm{a}} \pm 0.17$ & $0.468^{\mathrm{A}, \mathrm{a}} \pm 0.33$ \\
Cheese $+\mathrm{CEO}$ & $0.146^{\mathrm{B}, \mathrm{b}} \pm 0.28$ & $0.144^{\mathrm{B}, \mathrm{b}} \pm 0.33$ & $0.152^{\mathrm{B}, \mathrm{b}} \pm 0.33$ & $0.149^{\mathrm{B}, \mathrm{b}} \pm 0.19$ \\
\hline
\end{tabular}

Means \pm Std error. Different Capital letters within the same row are significantly different $(p \geq 0.005)$, different small letters within the same column are significantly different $(p \geq$ $0.005)$.

[53] reported in their study the inhibition of lipid oxidation in cheese supplemented with CEO.

\section{Conclusion}

The World Health Organization (WHO) Expert Committee on Food Additives has established the acceptable daily human intake of clove oil at $2.5 \mathrm{mg} / \mathrm{kg}$ bodyweight for humans. According to the data obtained from the present study, CEO was an effective antioxidant and had an antimicrobial potential that affected positively the quality of cheese. Based on the results above, CEO can be used for preserving cheese against pathogens and protecting it against lipid oxidation. The incorporation of CEO in cheese serves to maintain its nutritional quality and prolong its shelf life. 


\section{Conflicts of Interest}

The authors declare no conflicts of interest regarding the publication of this paper.

\section{References}

[1] Jeanet, R., Croguennec Schuck, P. and Brule, G. (2006) Science des aliments: Tome 2, Technologies des produits alimentaires. Tec \& Doc Lavoisier, Paris, 456 p.

[2] López-Pedemonte, T.J., Roig-Sagués, A.X., Trujillo, A.J., Capellas, M. and Guamis, B. (2003) Inactivation of Spores of Bacillus cereus in Cheese by High Hydrostatic Pressure with the Addition of Nisin or Lysozyme. Journal of Dairy Science, 86, 3075-3081. https://doi.org/10.3168/jds.S0022-0302(03)73907-1

[3] Scharfen, E.C., Mills, D.A. and Maga, E.A. (2007) Use of Human Lysozyme Transgenic Goat Milk in Cheese Making: Effects on Lactic Acid Bacteria Performance. Journal of Dairy Science, 90, 4084-4091. https://doi.org/10.3168/jds.2006-808

[4] Cristina, C., Annalisa, L., Fabio, L., Amalia, C. and Alessandro, D.N.M. (2017) Application of Preservation Strategies to Improve the Shelf Life of Spreadable Cheese. Food Packaging and Shelf Life, 11, 16-20. https://doi.org/10.1016/j.fpsl.2016.11.001

[5] Hasneen, D.F., Zaki, N.L., Abbas, M.S., Soliman, A.S., Ashoush, I.S. and Fayed, A.E. (2020) Comparative Evaluation of Some Herbs and Their Suitability for Skimmed Milk Yoghurt and Cast Kariesh Cheese Fortification as Functional Foods. Annals of Agricultural Sciences, 65, 6-12. https://doi.org/10.1016/j.aoas.2020.05.001

[6] El Hatmi, H., Jrad, Z., Mkadem, W., Chahbani, A., Oussaief, O., Ben Zid, M., Nouha, M., Zaidi, S., Khorchani, S., Belguith, K. and Mihoubi, N.B. (2020) Fortification of Soft Cheese Made from Ultrafiltered Dromedary Milk with Allium roseum Powder: Effects on Textural, Radical Scavenging, Phenolic Profile and Sensory Characteristics. LWT Food Science and Technology, 132, Article ID: 109885. https://doi.org/10.1016/j.lwt.2020.109885

[7] Sulejmani, E., Sahingil, D. and Hayaloglu, A.A. (2020) A Comparative Study of Compositional, Antioxidant Capacity, ACE-Inhibition Activity, RP-HPLC Peptide Profile and Volatile Compounds of Herbal Artisanal Cheeses. International Dairy Journal, 111, Article ID: 104837. https://doi.org/10.1016/j.idairyj.2020.104837

[8] Voon, H.C., Bhat, R. and Gulam, R. (2012) Flower Extracts and Their Essential Oils as Potential Antimicrobial Agents. Comprehensive Reviews Food Science and Food Safety, 11, 34-55. https://doi.org/10.1111/j.1541-4337.2011.00169.x

[9] Burt, S. (2004) Essential Oils: Their Antibacterial Properties and Potential Applications in Foods-A Review. International Journal of Food Microbiology, 94, 223-253. https://doi.org/10.1016/j.ijfoodmicro.2004.03.022

[10] Lanciotti, R., Gianotti, A., Patrignani, F., Belletti, N., Guerzoni, M.E. and Gardini, F. (2004) Use of Natural Aroma Compounds to Improve Shelf-Life and Safety of Minimally Processed Fruits. Trends in Food Science \& Technology, 15, 201-208. https://doi.org/10.1016/j.tifs.2003.10.004

[11] Bajpai, V.K., Sharma, A. and Baek, K.H. (2013) Antibacterial Mode of Action of Cudrania tricuspidata Fruit Essential Oil, Affecting Membrane Permeability and Surface Characteristics of Food-Borne Pathogens. Food Control, 32, 582-590. https://doi.org/10.1016/j.foodcont.2013.01.032

[12] Ben Ei Hadj Ali, I., Chaouachi, M., Bahri, R., Chaieb, I., Boussaïd, M. and Harzallah-Skhiri, F. (2015) Chemical Composition and Antioxidant, Antibacterial, Allelo- 
pathic and Insecticidal Activities of Essential Oil of Thymus algeriensis Boiss. et Reut. Industrial Crops and Products, 77, 631-639. https://doi.org/10.1016/j.indcrop.2015.09.046

[13] Holley, R.A. and Patel, D. (2005) Improvement in Shelf-Life and Safety of Perishable Foods by Plant Essential Oils and Smoke Antimicrobials. Food Microbiology, 22, 273-292. https://doi.org/10.1016/j.fm.2004.08.006

[14] Bakkali, F., Averbeck, S., Averbeck, D. and Idaomar, M. (2008) Biological Effects of Essential Oils-A Review. Food and Chemical Toxicology, 46, 446-475. https://doi.org/10.1016/j.fct.2007.09.106

[15] Ghasemnezhad, M., Sherafati, M. and Payvast, G.A. (2011) Variation in Phenolic Compounds, Ascorbic Acid and Antioxidant Activity of Five Coloured Bell Pepper (Capsicum annum) Fruits at Two Different Harvest Times. Journal of Functional Foods, 3, 44-49. https://doi.org/10.1016/j.jff.2011.02.002

[16] Kim, J., Marshall, M.R. and Wei, C.I. (1995) Antibacterial Activity of Some Essential Oil Components against Five Foodborne Pathogens. Journal of Agricultural and Food Chemistry, 43, 2839-2845. https://doi.org/10.1021/jf00059a013

[17] Artiga-Artigas, M., Acevedo-Fani, A. and Martín-Belloso, O. (2017) Improving the Shelf Life of Low-Fat Cut Cheese Using Nanoemulsion-Based Edible Coatings Containing Oregano Essential Oil and Mandarin Fiber. Food Control, 76, 1-12. https://doi.org/10.1016/j.foodcont.2017.01.001

[18] Bedoya-Serna, C.M., Dacanal, G.C., Fernandes, A.M. and Pinho, S.C. (2018) Antifungal Activity of Nanoemulsions Encapsulating Oregano (Origanum vulgare) Essential Oil: in Vitro Study and Application in Minas Padrão Cheese. Brazilian Journal of Microbiology, 49, 929-935. https://doi.org/10.1016/j.bjm.2018.05.004

[19] Can Seydim, A., Sarakus-Tutal, G. and Sogut, E. (2020) Effect of Whey Protein Edible Films Containing Plant Essential Oils on Microbial Inactivation of Sliced Kasar Cheese. Food Packaging and Shelf Life, 26, Article ID: 100567. https://doi.org/10.1016/j.fpsl.2020.100567

[20] Fancello, F., Petretto, G.L., Marceddu, S. and Severino Zara. T.V. (2020) Antimicrobial Activity of Gaseous Citrus limon var pompia Leaf Essential Oil against Listeria monocytogenes on Ricotta Salata Cheese. Food Microbiology, 87, Article ID: 103386. https://doi.org/10.1016/j.fm.2019.103386

[21] Gulcin, İ., Elmastaş, M. and Aboul-Enein, H.Y. (2012) Antioxydant Activity of Clove Oil-A Powerful Antioxidant Source. Arabian Journal of Chemistry, 5, 489-499. https://doi.org/10.1016/j.arabjc.2010.09.016

[22] Kamel, C. (2001) Tracing Modes of Action and Roles of Plant Extracts in NonRuminants. In: Garnsworthy, P.C. and Wiseman, J., Eds., Recent Advances in Animal Nutrition, Nottingham University Press, Nottingham, 130-150.

[23] Dragland, S., Senoo, H., Wake, K., Holte, K. and Blomhoff, R. (2003) Several Culinary and Medicinal Herbs Are Important Sources of Dietary Antioxydants. The Journal of Nutrition, 133, 1286-1290. https://doi.org/10.1093/jn/133.5.1286

[24] Thanissery, R., Kathariou, S. and Smith, D.P. (2014) Rosemary Oil, Clove Oil, and a Mix of Thyme-Orange Essential Oils Inhibit Salmonella and Campylobacter in Vitro. Journal of Applied Poultry Research, 23, 221-227. https://doi.org/10.3382/japr.2013-00888

[25] Smith-Palmer, A., Stewart, J. and Fyfe, L. (2001) The Potential Application of Plant Essential Oils as Natural Food Preservatives in Soft Cheese. Food Microbiology, 18, 463-470. https://doi.org/10.1006/fmic.2001.0415 
[26] Bakheit, A.M. and Foda, M.I. (2012) Sensory Evaluation and Antioxidant Activity of New Mudaffara Cheese with Spices under Different Storage Temperatures. Research Journal of Applied Sciences, 8, 3143-3150.

[27] Ghazghazi, H., Essghaier, B., Riguene, H., Rigane, G., El Aloui, M., Oueslati, M., Ben Salem, R., Sadfi Zouaoui, N., Nasera, Z. and Laarbi Khouja, M. (2019) A Phytochemical Analysis, Antioxidant and Antimicrobial Activities of Eucalyptus Essential Oil: A Comparative Study between Eucalyptus marginata L. and Eucalyptus paucilora L. Revue Romaine de Chimie, 64, 1055-1062.

https://doi.org/10.33224/rrch/2019.64.12.05

[28] Singleton, V.L., Orthofer, R. and Lamuela-Raventos, R.M. (1999) Analysis of Total Phenols and Other Oxidation Substrates and Antioxidants by Means of Folin-Ciocalteu Reagent. Methods in Enzymology, 299, 152-178.

https://doi.org/10.1016/S0076-6879(99)99017-1

[29] De carvalho, R.J., De souza, G.T., Honorio, V.G., De sousa, J.P., Da conceiḉăo, M.L. and Maganani, M. (2015) Comparative Inhibitory Effects of Thymus vulgaris L. Esential Oil against Staphylococcus aureus, Listeria monocytogenes and Mesophilic Starter Co-Culture in Cheese-Mimicking Models. Food Microbiology, 52, 59-65. https://doi.org/10.1016/j.fm.2015.07.003

[30] Al-Aamri, M.S., AL-Aboussi, N.M., Al-Jabri, S.S., Alam, T. and Khan, S.A. (2018) Chemical Composition and In-Vitro Antioxidant and Antimicrobial Activity of the Essential Oil of Citrus aurantifolia L. Leaves Grown in Eastern Oman. Journal of Taibah University Medical Sciences, 13, 108-112.

https://doi.org/10.1016/j.jtumed.2017.12.002

[31] Hassanie, M.F.R., Mahgoub, S.A. and El-Zahar, K.M. (2014) Soft Cheese Supplemented with Black Cumin Oil: Impact on Food Borne Pathogens and Quality during Storage. Saudi Journal of Biological Sciences, 21, 280-288.

https://doi.org/10.1016/j.sjbs.2013.10.005

[32] Yang, B., Zhao, H., Cui, S., Wang, Y., Xia, X., Xi, M., Wang, X., Meng, J. and Ge, W. (2014) Prevalence and Characterization of Salmonella enterica in Dried MilkRelated Infant Foods in Shaanxi, China. Journal of Dairy Science, 97, 6754-6760. https://doi.org/10.3168/jds.2014-8292

[33] TuğçeTunç, M. and Koca, İ. (2019) Ohmic Heating Assisted Hydrodistillation of Clove Essential Oil. Industrial Crops and Products, 141, Article ID: 111763. https://doi.org/10.1016/j.indcrop.2019.111763

[34] Hudaib, M. and Aburjai, T. (2007) Volatile Components of Thymus vulgaris L. from Wild-Growing and Cultivated Plants in Jordan. Flavour and Fragrance Journal, 22, 322-327. https://doi.org/10.1002/ffj.1800

[35] Hossain, M.A., Rashid Al Harbi, S.R., Mohamed Weli, A., Al-Riyami, Q. and Al-Sabahi, J.N. (2014) Comparison of Chemical Constituents and Antimicrobial Activities of Three Essential Oils from Three Different Brands' Clove Samples Collected from Gulf Region. Asian Pacific Journal of Tropical Disease, 4, 262-268. https://doi.org/10.1016/S2222-1808(14)60570-3

[36] Mektrirata, R., Janngeon, K., Pikulkaewc, S. and Okonogi, S. (2016) Evaluation of Cytotoxic and Inflammatory Properties of Clove Oil Microemulsion in Mice. Asian Journal of Pharmaceutical Science, 11, 231-232. https://doi.org/10.1016/j.ajps.2015.11.020

[37] Silvestri J.D.F., Paroul N., Czyewski E., et al. (2018) Perfil da composição química e atividadesantibacteriana e antioxidante do oleoessencial do cravo-da-índia (Eugenia caryophyllata Thunb.). Revista Ceres, 57, 589-594.

https://doi.org/10.1590/S0034-737X2010000500004 
[38] Radünz, M., Martins da Trindade, M.L., Radünz, A.L., Dellinghausen Borges, C., Avila Gandra, E. and Helbig, E. (2018) Antimicrobial and Antioxidant Activity of Unencapsulated and Encapsulated Clove (Syzygium aromaticum, L.) Essential Oil. Food Chemistry, 276, 180-186. https://doi.org/10.1016/j.foodchem.2018.09.173

[39] Zhang, Y., Wang, Y., Zhu, X., Cao, P., Wei, S. and Lu, Y. (2017) Antibacterial and Antibiofilm Activities of Eugenol from Essential Oil of Syzygium aromaticum (L.) Merr. \& L. M. Perry (Clove) Leaf against Periodontal Pathogen Porphyromonas gingivalis. Microbial Pathogenesis, 113, 396-402.

https://doi.org/10.1016/j.micpath.2017.10.054

[40] Ebani, V.V., Najar, B., Bertelloni, F., Pistelli, L., Mancianti, F. and Nardoni, S. (2018) Chemical Composition and in Vitro Antimicrobial Efficacy of Sixteen Essential Oils against Escherichia coli and Aspergillus fumigates Isolated from Poultry. Journal of Veterinary Science, 5, Article No. 62.

https://doi.org/10.3390/vetsci5030062

[41] Teles, A.M., Silva-Silva, J.V., Fernandes, J.M.P., Abreu-Silva, A.L., da Silva Calabrese, K., Filho, N.E.M., Mouchrek, A.N. and Almeida-Souza, F. (2021) GC-MS Characterization of Antibacterial, Antioxidant, and Antitrypanosomal Activity of Syzygium aromaticum Essential Oil and Eugenol. Evidence-Based Complementary and Alternative Medicine, 2021, Article ID: 6663255. https://doi.org/10.1155/2021/6663255

[42] Babaglu, H.C., Bayrak, A., Ozdemir, N. and Ozgun, N. (2017) Encapsulation of Clove Essential Oil in Hydroxypropyl Beta-Cyclodextrin for Characterization, Controlled Release, and Antioxidant Activity. Journal of Food Processing and Preservation, 41, e13202. https://doi.org/10.1111/jfpp.13202

[43] Lee, W.G. and Shibamoto, T. (2001) Antioxidant Property of Aroma Extract Isolated from Clove Buds. Food Chemistry, 74, 443-448. https://doi.org/10.1016/S0308-8146(01)00161-3

[44] Shan, B., Cai, Y.Z., Sun, M. and Corke, H. (2005) Antioxidant Capacity of 26 Spice Extracts and Characterization of Their Phenolic Constituents. Journal of Agricultural and Food Chemistry, 53, 7749-7759. https://doi.org/10.1021/jf051513y

[45] Shabir, G., Anwar, F., Sultana, B., Khalid, Z.M., Afzal, M., Khan Q.M. and Ashrafuzzaman. M. (2011) Antioxidant and Antimicrobial Attributes and Phenolics of Different Solvent Extracts from Leaves, Flowers and Bark of Gold Mohar. Molecules, 16, 7302-7319. https://doi.org/10.3390/molecules16097302

[46] Burt, S.A. and Reinders, R.D. (2003) Antibacterial Activity of Selected Plant Essential Oil against Escherchia coli O157:H7. Letters in Applied Microbiology, 36, 162-167. https://doi.org/10.1046/j.1472-765X.2003.01285.x

[47] Dorman, H.J. and Deans, S.G. (2000) Antimicrobial Agents from Plants: Antibacterial Activity of Plant Volatile Oils. Journal of Applied Microbiology, 88, 308-316. https://doi.org/10.1046/j.1365-2672.2000.00969.x

[48] Smith-Palmer, A.J., Stewart, J. and Fyfe, L. (1998) Antimicrobial Properties of Plant Essential Oils and Essences against Five Important Food-Borne Pathogens. Letters in Applied Microbiology, 26, 118-122. https://doi.org/10.1046/j.1472-765X.1998.00303.x

[49] Hammer, K.A., Carson, C. and Riley, T. (1999) Antimicrobial Activity of Essential Oils and Other Plant Extracts. Journal of Applied Microbiology, 86, 985-990. https://doi.org/10.1046/j.1365-2672.1999.00780.x

[50] Oueslati, S., Trabelsi, N., Boulaaba, M., Legault, J. and Ksouri, R. (2012) Evaluation of Antioxidant Activities of the Edible and Medicinal Suaeda Species and Related 
Phenolic Compounds. Industrial Crops and Products, 36, 513-518.

https://doi.org/10.1016/j.indcrop.2011.10.006

[51] Olivera, M.S., Costa, W.A., Pereira, D.S., Botelho, J.R.S., Menezes, T.O.A, Andrade, E.H.A., Silva, S.H.M., Filho, A.P.S.S. and Carvalho, R.N. (2016) Chemical Composition and Phytotoxic Activity of Clove (Syzygium aromaticum) Essential Oil Obtained with Supercritical $\mathrm{CO}_{2}$. The Journal of Supercritical Fluids, 118,185-193. https://doi.org/10.1016/j.supflu.2016.08.010

[52] Yamaguchi, T., Takamura, H., Matoba, T. and Ferao, J. (1998) HPLC Method for the Evaluation of the Free Radical-Scavenging Activity of Foods by Using 1,1-Diphenyl2-Picrylhydrazyl. Bioscience, Biotechnology, and Biochemistry, 62, 1201-1204. https://doi.org/10.1271/bbb.62.1201

[53] Shan, B., Cai, Y.Z., Brooks, J.D. and Corke, H. (2011) Potential Application of Spice and Herb Extracts as Natural Preservatives in Cheese. Journal of Medicinal Food, 14, 284-290. https://doi.org/10.1089/jmf.2010.0009 